\title{
Fundamental Analysis of Financial Ratios on Stock Prices
}

Deden Tarmidi ${ }^{1 *}$, Rachmat Pramukty ${ }^{2}$, Taufik Akbar ${ }^{1}$

${ }^{1}$ Universitas Mercu Buana, Jakarta, Indonesia

${ }^{2}$ Universitas Bhayangkara Jakarta Raya, Jakarta, Indonesia

DOI: $10.36348 /$ sjef.2020.v04i05.003

| Received: 17.05.2020 | Accepted: 26.05.2020 | Published: 28.05.2020

*Corresponding author: Deden Tarmidi

Abstract

This study is a follow-up study of research on stock prices that have been conducted by researchers, but this research focuses on the fundamental analysis of the impact of financial ratios before and after being published on stock prices. As in the signal theory that management will always try to give a positive signal to the market to be captured well so as to increase the value of the company which is reflected in the entity's stock price on the exchange, one of which is by publishing financial statements. This study analyzes more deeply the effect of financial ratios including Return On Assets (ROA), Net Profit Margin (NPM) and Debt to Equity Ratio (DER) on stock prices before and after the publication of financial statements. Using panel data with STATA, it was found that the effect of ROA and NPM on stock prices after publication was stronger than before publication, while the effect of DER was found to be the opposite. With these results concluded that financial ratios are still one of the benchmarks used by investors in their transactions in the stock market.

Keywords: Stock Prices, ROA, NPM, DER.

Copyright @ 2020: This is an open-access article distributed under the terms of the Creative Commons Attribution license which permits unrestricted use, distribution, and reproduction in any medium for non-commercial use (NonCommercial, or CC-BY-NC) provided the original author and source are credited.

\section{INTRODUCTION}

At present, shares are an investment choice for the public or investors because they provide substantial profits. However, behind large profits, there is also a large risk or often known as high risk high return. Every person who invests, must be prepared to accept risk, not only expecting profit. The condition of stock prices on the exchange will not always be stable, the price of these shares will increase or decrease every day or even in a matter of minutes. Investors must also be observant in reading the financial statements published by the company.

With the ups and downs of stock prices on the exchange, investors need techniques in choosing companies to invest their shares in these companies. It is very important for market participants to know how to analyze stocks. This stock analysis is needed because in investing investors always deal with the stock market. In analyzing these shares the investor first knows the fundamental aspects of the stock. The fundamental aspects of the stock are related to financial performance, the company's industry, including the company's revenue and sales structure. In addition to taking a fundamental approach, investors can also approach the stock analysis through a technical approach. How to analyze stocks based on fundamental and technical approaches is a capital analysis that many investors do in predicting stock prices on the Indonesia Stock Exchange [1].

Until now, financial ratios are still widely used by investors in analyzing entity stock prices because financial ratios are one of the measuring tools in assessing financial condition and company performance [2]. Some financial ratios that are widely analyzed in assessing stock prices are profitability ratios with Return on Assets (ROA) and Net Profit Margin (NPM) indicators, leverage ratios with Debt to Equity Ratio (DER) indicators.

Research on the effect of Return On Assets (ROA) on stock prices has been conducted by Octaviani \& Komalasarai [3] and Purnamasari [4] found a positive effect of Return On Assets (ROA) on stock prices. In addition, not a few studies have analyzed the effect of Net Profit Margin (NPM) on stock prices. Dita \& Murtaqi [5] found a positive influence on Net Profit Margin (NPM) on stock prices, while Kusmayadi, et al. [6] found a negative effect of NPM on stock returns. 
Pratama \& Erawati [7] and Dita \& Murtaqi [5] in their research found a positive effect of Debt to Equity Ratio (DER) on stock prices. These results contradict the research of Harahap [8] and Firdaus [9] who did not find the effect of Debt to Equity Ratio (DER) on stock prices.

Strengths of this research are the use of 2 (two) stock price measurements, namely before publication and after publication. This was done to confirm the results of previous studies on the impact of financial ratios on stock prices. Stock closing at the end of the year is used as an investor reaction to entities listed on the Stock Exchange before annual reports and financial statements are published. While the publication date is the upload date of the annual report and financial report which can be viewed from the website idx.co.id, shares on that date are the investor's reaction to the company's performance published through the annual report and the entity's financial statements.

Based on the background above and the research gap found in previous studies, researchers are interested in doing a re-analysis with two different methods of analysis to confirm the effect of financial ratios that are focused on profitability ratios and solvency ratios to stock prices before and after publication in the manufacturing sector listed on the Indonesia Stock Exchange in the 2014-2018 period.

\section{LITERATURE REVIEW Theoritical Framework}

Signaling theory was first introduced by Spence in his research entitled Job Market Signaling [11] in Gayatri [10] argues that a signal or signal gives a signal, the sender (owner of information) tries to provide a piece of relevant information that can be utilized by the recipient. The recipient will then adjust his behavior according to his understanding of the signal. Signaling theory suggests how a company should give signals to users of financial statements. This signal is in the form of information about what management has done to realize the owner's wishes. Signals can be in the form of promotions or other information stating the company is better than other companies.

Information published by the company as an announcement will give a signal to investors in making investment decisions [12]. If the announcement contains a positive value, then the market is expected to react when the announcement is received by the market. Once received, market participants will then analyze the information announced as a good signal (good news) or bad signal (bad news). Signals given by the company to outsiders can reduce information asymmetry if the information provided by the company provides positive and trustworthy information so as to reduce uncertainty about the company's future prospects, it will have an impact on the company's credibility and success [13].
Signaling theory has a close relationship with financial statement information [14], information in the form of ROA or the rate of return on assets or also how much profit is derived from the assets used. Thus if ROA is high then it will be a good signal for investors. Because with a high ROA shows that the company's financial performance is good, investors will be interested in investing their funds in the form of securities or shares. A lot of stock demand will make the stock price increase. High profitability, and Leverage that is not too high and not too low shows a good prospect of the company, so investors will respond to this positive signal and the value of the company and company stock prices will increase.

\section{Conceptual Framework and Hypothesis Development}

Return on Assets is used to measure the overall effectiveness in generating profits with available assets. The more effective the assets of the company in generating profits, the better the company becomes an investment choice and will affect its stock price. The same thing was found in previous studies that Return On Assets has a significant effect on stock prices [3]. However, at the end of the financial year, the company has not yet published audited financial statements, only quarterlies financial statements published by the entity itself without any opinion from an external audit are guaranteed integrity. So the investor's reaction to the stock price is expected to be stronger after the publication of financial statements.

\section{H1. Return On Assets (ROA) have a stronger influence on stock prices after publication than before publication}

Net Profit Margin is the ratio of company profit rate from each number of opinions received. The higher the NPM of a company indicates that the company has succeeded in increasing revenue and efficiency of the company's burden so that it is often used as an indicator of company performance. This performance attracted investors and the public to conduct stock transactions with companies because the higher the value of NPM, the better the quality of management in managing the company. This is in line with Dita \& Murtaqi [5] and Kusmayadi, et al. [6] who in his research found the effect of Net Profit Margin (NPM) on stock prices.

\section{H2. Nett Profit Margin (NPM) has a stronger influence on stock prices after publication than before publication}

High Debt to Equity Ratio shows that the company is considered good by creditors in managing their company, and is considered able to pay their debts. Thus, given a high loan by creditors exceeds the capital owned by the company. This was responded well by investors who also thought that a company that had a 
high Debt to Equity Ratio (DER) value, then the company had a good performance, so investors were interested in buying the company's shares. In his research, Pratama \& Erawati [7] found the effect of Debt to Equity Ratio (DER) on stock prices.

\section{H3. Debt to Equity Ratio (DER) has a stronger influence on stock prices after publication than before publication}

\section{METHODOLOGY \\ Population and Sample}

The population of this research is the manufacturing sector companies listed on the Indonesia Stock Exchange in the period 2014 - 2018. The sample selection is done by purposive sampling method with the following criteria: 1) Having a fully published financial report for 5 years (2014-2018), 2) Have complete analysis data on published reports. Of the total 144 manufacturing companies listed on the Indonesia Stock Exchange, there are 199 companies sampled because they are in accordance with the criteria and do not have outlier data, so that with 5 years of observation there are 595 data analyzed.

\section{Operational Variable}

Stock Price is the dependent variable in this study. Share price is the value of shares in rupiah formed as a result of buying and offering of shares on the stock exchange by fellow exchange members [12]. Adopting the study of Fahlevi, et al. [16], the share price in this study is measured by the closing stock price at the end of the financial year and the closing stock price on the date of publication of financial statements on the stock exchange.
Adopting Fahmi [17], ROA is measured by dividing profit after tax by Total Assets. NPM is measured by dividing profit after tax by the number of sales, while DER is measured by dividing the amount of debt by the amount of equity.

\section{Hypothesis Testing Method}

STATA software is used to analyze data in the classical assumption test, the selection of the best model and also hypothesis testing. The classic assumption test is performed to see the quality of the data. In the normality test it is known that the sign value is 0.162 which means above 0.05 so that the research data is normal, as well as a vif value of less than 10 indicates that the data is free from multicollinearity. In the heteroscedasticity and autocorrelation test it was found that the Prob value was 0.0000 which was below 0.05 so that the symptoms of heteroscedasticity and autocorrelation occurred. Then the data is improved with Prais Winsten and Robust so that the data is better.

The selection of the best model is done by the chow test, LM test and Hausman test. In the chow test found a value of Prob 0.0000 which explains that the Fixed model effect is better than the common model effect. In the LM test found a value of Prob 0.0000 which explains that the random model effect is better than the common model effect. Whereas the Hausman test found a value of Prob 0.0000 which explains that the fixed model effect is better than the random model effect. So it can be concluded that the fixed effect model is better than the common model effect and the random model effect. The results of selecting the best model were found to be the same both in the first regression model and in the second regression model.

Table-1: Hypothesis Test

\begin{tabular}{|c|c|c|c|c|c|c|}
\hline \multirow[t]{2}{*}{ Variable } & \multicolumn{3}{|c|}{$\begin{array}{c}\text { Stock Price Before Publication } \\
\text { of Financial Statement (Y1) }\end{array}$} & \multicolumn{3}{|c|}{$\begin{array}{c}\text { Stock Price After Publication } \\
\text { of Financial Statement (Y2) }\end{array}$} \\
\hline & Coeffisient & Prob $>t$ & stat & Coeffisient & Prob > & -stat \\
\hline ROA (X1) & 0.60469 & 0.016 & $* *$ & 0.71875 & 0.005 & $* * *$ \\
\hline NPM (X2) & -0.00623 & 0.970 & & -0.12838 & 0.453 & \\
\hline DER (X3) & 0.01888 & 0.225 & & 0.01449 & 0.360 & \\
\hline $\mathrm{N}$ & & 595 & & & 595 & \\
\hline R-Square & & 0.1469 & & & 0.1607 & \\
\hline Prob F & & 0.0235 & $* *$ & & 0.0221 & $* *$ \\
\hline
\end{tabular}

Table 1 shows that ROA has a significant effect on shares at the end of the year and shares at the date of publication of the financial statements. Significant differences are found that the effect of ROA is stronger on stock prices after the publication of financial statements than at the end of the year before publication. These results explain that hypothesis 1 is accepted.

Table 1 also found that NPM had no significant effect on year-end stock prices and shares at the date of publication of the financial statements.
Although both have no influence, it is known from the significance value that the effect of NPM on stock prices is stronger after the publication of financial statements than at the end of the year before the publication of financial statements. These results explain that hypothesis 2 is accepted.

Table 1 also found that DER had no significant effect on year-end stock prices and shares at the date of publication of the financial statements. Although it does not have a strong influence, it is known from the significance value that the effect of DER on stock 
prices is stronger at the end of the year before publication than after the publication of financial statements. These results explain that hypothesis 3 is rejected.

\section{RESULT AND DISCUSSION}

This study found that the effect of ROA was stronger on stock prices after the publication of financial statements than at the end of the year before publication. These results explain that ROA which is a financial ratio affects investors or the public in assessing company performance so that it is interested in increasing share purchase transactions and increasing share prices as the law of demand. The effect of ROA on stock prices is in line with research by Octaviani \& Komalasarai [3] and Purnamasari [4].

Although both do not have a significant effect on stock prices, but from the significance value it is known that the influence of NPMs on stock prices is stronger after the publication of financial statements than at the end of the year before the publication of financial statements. These results explain that NPM which is a financial ratio affects investors or the public in assessing the company's performance even though it is weak. The insignificant negative effect of NPM on stock prices is not in line with the research of Kusumayadi, et al. [6].

This study did not find the effect of DER on year-end stock prices and shares on the date of publication of the financial statements. Although it does not have a strong influence, it is known from the significance value that the effect of DER on stock prices is stronger at the end of the year before publication than after the publication of financial statements. These results explain that investors are not too concerned about the level of corporate debt so that it does not affect stock transactions in the market either at the end of the year before the publication of financial statements and after the publication of financial statements. No discovery of the effect of DER on stock prices is in line with research by Harahap [8] and Firdaus [9].

\section{CONCLUSIONS \& SUGESTIONS}

The results of this study found the following:

1. ROA affects stock prices more strongly after the publication of financial statements than before the publication of financial statements. These results can be a reference for company management to improve company performance so that many public and investors are interested in the company's shares so that the price increases.

2. The effect of NPM on stock prices is weaker before the publication of financial statements than afterwards. These results can be a reference for further researchers to analyze other sectors in their effects on stock prices.
3. The effect of DER on stock prices is weaker after the published financial statements compared to before.

\section{ACKNOWLEDGMENT}

This research is the result of a collaboration between Universitas Mercu Buana and Universitas Bhayangkara Jakarta Raya. Hopefully this collaboration will improve the performance of lecturers in each university. The research team would like to thank the assistance of the rector, deans and research centers at each university for helping to carry out this successful collaboration.

\section{REFERENCES}

1. Agustian, W. (2016). Pentingnya Investor Mengerti Cara Menganalisa Saham. Retrieved from economy.okezone.com website: https://economy.okezone.com/read/2016/09/07/278 /1483834/pentingnya-investor-mengerti-caramenganalisa-saham

2. Hery. (2018). Pengantar Akuntansi - Hery, SE Google Books. Retrieved from https://books.google.co.id/books?id=gsBGDwAAQ BAJ\&printsec $=$ frontcover $\& \mathrm{dq}=$ akuntansi\&hl=ban $\& s a=X \& v e d=0 a h U K E w i C 14 S V k s D j A h W T 73 M B$ HaJUCygQ6AEILzAC\#v=onepage\&q=akuntansi\& $\mathrm{f}=$ false

3. Octaviani, S., \& Komalasarai, D. (2017). Pengaruh Likuiditas, Profitabilitas, Dan Solvabilitas Terhadap Harga Saham (Studi Kasus pada Perusahaan Perbankan yang Terdaftar di Bursa Efek Indonesia). Jurnal Akuntansi., 3(2), 77-89.

4. Purnamasari, D. (2015). The Effect of Changes in Return on Assets , Return on Equity , and Economic Value Added to the Stock Price Changes and Its Impact on Earnings Per Share. Journal of Accounting (ISSN 2222-2847), 6(6), 80-90. https://doi.org/10.1109/TUFFC.2007.251

5. Dita, A.H., \& Murtaqi, I. (2014). The Effect of Net Profit Margin, Price to Book Value and Debt Equity Ratio to Stock Return in Indonesian Consumer Good Industry. Journal of Business and Management, 3(3), 305-315.

6. Kusmayadi, D., Rahman, R., \& Abdullah, Y. (2018). Analysis of the Effect of Net Profit Margin, Price to Book Value, and Debt to Equity Ratio on Stock Return. International Journal of Recent Scientific Research, 9(7F), 28091-28905.

7. Pratama, A., \& Erawati, T. (2016). Pengaruh Current Ratio, Debt To Equity Ratio, Return On Equity, Net Profit Margin Dan Earning Per Share Terhadap Harga Saham (Study Kasus Pada Perusahaan Manufaktur Yang Terdaftar Di Bursa Efek Indonesia Periode 2008-2011). Jurnal Akuntansi, 2(1). https://doi.org/10.24964/ja.v2i1.20

8. Harahap, I. M (2018). Impact of Macroeconomic Variables and Financial Performance on Stock Prices of Oil and Gas Mining. International 
Journal of Economics, Business and Management Research, 2(5), 1-11.

9. Firdaus, I. (2018). Pengaruh Current Ratio, Debt to Equity Ratio dan Price Book Value Terhadap Harga Saham Pada Sub Sektor Transportasi yang Tedaftar di BEI Periode 2012-2016. Jurnal Ekonomi, 23(3), 403-416.

10. Gayatri, N.W.P.D (2019). Risiko Kredit, Risiko Likuiditas, Risiko Operasional Dan Profitabilitas. Jurnal Riset Akuntansi, 9, 73-83.

11. Spence, M. (1973). Job Market Signalling. The Quarterly Journal of Economics, 87(3), 355-374.

12. Hartono, J. (2014). Teori Portofolio dan Analisis Investasi (Edisi Ketiga) (Kesembilan). Retrieved from

https://scholar.google.com.sg/citations?user=6eDyh RgAAAAJ\&hl=en
13. Triani, N., \& Tarmidi, D. (2019). Firm Value: Impact of Investment Decisions, Funding Decisions and Dividend Policies. International Journal of Academic Research in Accounting, Finance and Management Sciences, 9(2), 158-163.

14. Tarmidi, D., Fitria, G.N., \& Ahmad, Z. (2019). Financial Performance and Audit Quality: Comparative Study of Investor Reaction. Scholars Bulletin, 5(12), 825-830.

15. Hadi, N. (2013). Pasar Modal. Yogyakarta: Graha Ilmu.

16. Fahlevi, R. R., Asmapane, S., \& Oktavianti, B. (2018). Pengaruh kinerja keuangan terhadap harga saham pada perusahaan perbankan yang terdaftar di Bursa Efek Indonesia. Akuntabel, 15(1), 39-48.

17. Fahmi, I. (2015). Analisis Laporan Keuangan. ALFABETA. 